\title{
Utilization of alternative fuels and materials in cement kiln towards emissions of benzene, toluene, ethyl-benzene and xylenes (BTEX)
}

\author{
Ulfi Muliane* and Puji Lestari \\ Department of Environmental Engineering, Institut Teknologi Bandung (ITB), 40132 Bandung, Indonesia
}

\begin{abstract}
Co-processing in cement industry has benefits for energy conservation and waste recycling. Nevertheless, emissions of benzene, toluene, ethyl-benzene, and xylenes (BTEX) tend to increase compared to a non co-processing kiln. A study was conducted in kiln feeding solid AFR (similar to municipal solid waste, MSW) having production capacity 4600-ton clinker/day (max. 5000 ton/day) and kiln feeding biomass having production capacity 7800-ton clinker/day (max. 8000 ton/day). The concentration of VOCs emissions tends to be higher at the raw mill on rather than the raw mill off. At the raw mill on, concentration of total volatile organic carbon (VOCs) emission from cement kiln stack feeding Solid AFR 1, biomass, Solid AFR 2, and mixture of Solid AFR and biomass is $16.18 \mathrm{mg} / \mathrm{Nm}^{3}, 16.15 \mathrm{mg} / \mathrm{Nm}^{3}, 9.02$ $\mathrm{mg} / \mathrm{Nm}^{3}$, and $14.11 \mathrm{mg} / \mathrm{Nm}^{3}$ respectively. The utilization of biomass resulted in the lower fraction of benzene and the higher fraction of xylenes in the total VOCs emission. Operating conditions such as thermal substitution rate, preheater temperature, and kiln speed are also likely to affect BTEX emissions.
\end{abstract}

\section{Introduction}

Cement is an energy-intensive industry that takes into account at around $35 \%$ for energy cost [1]. It requires a high need of funding for fossil fuel consumption. There is a technique called co-processing that utilized alternative fuels in the manufacturing process in order to decrease the cost of fossil fuel consumption [2]. The similar characteristics between cement kiln and incinerator make the cement kiln operated as disposal facilities as well as utilized waste as secondary fuel [3]. A ton of coal can be substituted by 1.6-ton rice husk as AFR in the cement plant [4]. In addition to resources and energy conservation, the $\mathrm{CO}_{2}$ emissions from cement kiln stack through co-processing activities can reduce up to 0.118 ton $\mathrm{CO}_{2}$ /ton clinker in $40 \%$ thermal substitution rate (TSR) [5].

In spite of its benefit, BTEX emissions from coprocessing kiln are likely higher compared to a non coprocessing kiln. BTEX are considered as main sources of secondary organic aerosols [6] that contribute to the attenuation of regional visibility, climate change, and potential health hazards [7]. Based on a research in Canada, benzene is associated with an increased risk of cancer (leukemia and lungs) and cancer-related mortality [8].

BTEX emissions from non-coprocessing kiln are in the range $2.346-3.458 \mathrm{mg} / \mathrm{Nm}^{3}$ [9] while from coprocessing kiln utilized various of waste are in the range 1.859 - $46.804 \mathrm{mg} / \mathrm{Nm}^{3}$ [9]. Based on Fatimah [9] findings, the average of BTEX concentrations from kiln using AFR varies from $0.5-20$ times higher than kiln utilized coal only. BTEX emissions from cement industry are formed by decomposition of the organic constituent in a preheater $[10,11]$. Emission factor of benzene from cement kiln using ESP as air pollution control is $0.0016 \mathrm{~kg} /$ ton cement while for toluene, ethylbenzene, and xylene is $0.00010 \mathrm{~kg} /$ ton cement, $9.5 \times 10^{-6}$ $\mathrm{kg} /$ ton cement, and $6,5 \times 10^{-5} \mathrm{~kg} /$ ton cement respectively [12]. For overall VOCs, in European countries, the emission factor of VOCs is $52.4 \mathrm{~g} /$ ton clinker with exhaust volume of kiln gas $2300 \mathrm{Nm}^{3}$ /ton clinker [13].

Based on EU Directive 2000/76/EC, the daily average limit for BTEX emissions along with other volatile organic compounds (VOCs) from incineration or co-incineration process is $10 \mathrm{mg} / \mathrm{m}^{3}$ (dry, $273 \mathrm{~K}, 1013$ $\mathrm{hPa}, 10 \% \mathrm{O}_{2}$ ) as total organic carbon (TOC) parameter. The high temperature $\left(1200\right.$ to $\left.2000^{\circ} \mathrm{C}\right)$ and residence time over two seconds at that temperature result in complete destruction of toxic compound in secondary fuel up to $99.99 \%$ inside the kiln [3]. Nonetheless, VOCs emission from cement kiln stack still exceeds the limit of the threshold. The mechanism of BTEX formation from cement kiln with AFR utilization is not clear. Therefore, it is essential to conduct a study of waste utilization as AFR in cement manufacturing and its relationship with BTEX emission as a preliminary study for further application towards the sustainable industry.

\footnotetext{
Corresponding author: ulfimuliane@tl.itb.ac.id
} 


\section{Materials and Method}

The research began with collecting gas samples from kiln stack and AFR from silo prior to preheater/precalciner systems followed by laboratory analysis. Gas samples from cement kiln stack were collected through active method sampling using sampling train. BTEX is a group of organic volatile compounds (VOCs) that became the target of sampling. As VOCs, BTEX exists in the gas phase from cement kiln stack thus sampling was conducted in a non-isokinetic condition in the flow rate of 1 liter per minute for 30 minutes. Activated Charcoal Type G (Drāger Safety AG \& Co.KgaA) along with DESAGA Gas Samplers GS 212 are used to collect the samples. Then, samples were analyzed using GC-MS (gas chromatography - mass spectrometry) referred to EN 13649 (Determination of the mass concentration of individual gaseous organic compounds: activated carbon and solvent desorption method).

In regard to find out the relationship between BTEX emission and utilization of AFR, calculation of TSR in which the amount of energy replaced by AFR is important. Eq. 1 shows the calculation of TSR where $\mathrm{q}_{\mathrm{AF}}$ is the quantity of AFR [ton/hour], $\mathrm{q}_{\mathrm{C}}$ is the quantity of coal [ton/hour], $\mathrm{CV}_{\mathrm{AFR}}$ is the calorific value of AFR $[\mathrm{MJ} / \mathrm{kg}]$, and $\mathrm{CV}_{\mathrm{C}}$ is the calorific value of coal $[\mathrm{MJ} / \mathrm{kg}]$.

$$
T S R=\frac{\sum_{1}^{n}\left(q_{A F} \times C V_{A F}\right)}{\sum_{1}^{n}\left(q_{A F} \times C V_{A F}\right)+\sum_{1}^{n}\left(q_{C} \times C V_{C}\right)}
$$

In addition to flue gas and AFR analysis, operating conditions during cement manufacturing process were also recorded including raw mill condition, preheater temperatures, kiln temperatures, and kiln speed. For kiln residence time, it is calculated as a function of kiln speed as shown in Eq. 2, where $t$ is material residence time [min], L is kiln length [m], $\Theta$ is angle of repose of material $\left[^{\circ}\right], \mathrm{v}$ is slope of kiln $\left[^{\circ}\right], \mathrm{D}$ is kiln shell diameter $[\mathrm{m}]$, Lining is refractory thickness [m], rpm is kiln rotation per minute [rpm], and $\mathrm{F}$ is factor of kiln diameter constant.

$$
t=\frac{1,77 \times L \times \sqrt{\Theta}}{v \times(D-2 \times \text { Lining }) \times r p m} \times F
$$

This research was conducted in an actual scale of cement plant having production capacity 5.6-million-ton cement/year. There is two kiln involved in the study, first kiln feeding solid AFR (similar to MSW) having production capacity 4600-ton clinker/day (max. 5000 ton/day) and second kiln feeding biomass having production capacity 7800-ton clinker/day (max. 8000 ton/day).

Each kiln stack is equipped with ESP as air pollution control. Kiln 1 has a 4.5 -meter-high stack with $15.904 \mathrm{~m}^{2}$ of diameter and kiln 2 has a 5.6-meter-high stack with $25.518 \mathrm{~m}^{2}$ of diameter. There is two sampling condition involving ESP namely raw mill on and raw mill off. In raw mill on condition, the exhaust gas from the burner and preheater pass through the raw mill then the ESP. Dust from ESP will be returned to the preheater while the clean gas will go out from the stack. When sampling in the raw mill off condition, the exhaust gas from burner and preheater will directly go to the conditioning tower followed by ESP.

\section{Results and Discussion}

The source of the air pollutant from cement kiln stack can be classified into three types i.e. raw materials, fuels and process inside kiln system [14]. In addition to AFR characteristics, there is also an influence of operating condition towards emission from cement kiln stacl. TSR, preheater temperature, kiln speed, and kiln residence time show a relationship with each compound in the flue gas.

From the flue gas analysis, it was found that not only BTEX presented in the cement kiln stack emission. Other VOCs such as nonane, octane, and decane were also existed and it will also be discussed as non-BTEX emission. The BTEX and non-BTEX emission henceforward will be discussed together in term of VOCs emission.
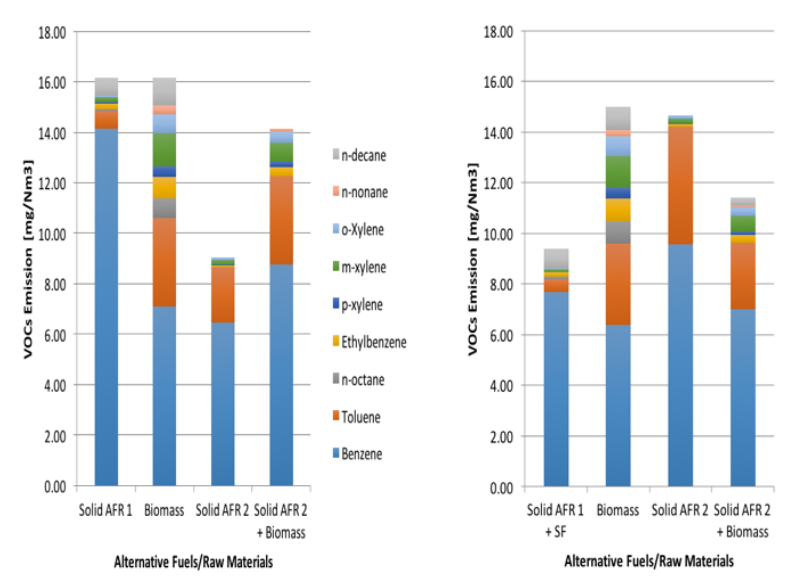

Fig. 1. VOCs emission at different sampling condition: (a) raw mill on and (b) raw mill off

Fig. 1 presents the average concentration of VOCs element in two different sampling condition i.e. raw mill on and raw mill off. The concentration of total VOCs at the raw mill on condition is relatively higher than at the raw mill off, except for Solid AFR 2 fuels. Total VOCs from kiln fed Solid AFR 1 at the raw mill on is 16.18 $\mathrm{mg} / \mathrm{Nm}^{3}$ and $9.41 \mathrm{mg} / \mathrm{Nm}^{3}$ at raw mill off. For kiln substituted with biomass, the VOCs emission is 16.15 $\mathrm{mg} / \mathrm{Nm}^{3}$ with the raw mill on while raw mill of is slightly lower at $14.98 \mathrm{mg} / \mathrm{Nm}^{3}$. Then for a kiln with a mixed fuel of Solid AFR 2 and biomass, the total concentration of VOCs is also higher at raw mill compared to raw mill off at $14.11 \mathrm{mg} / \mathrm{Nm}^{3}$ and 11.18 $\mathrm{mg} / \mathrm{Nm}^{3}$ respectively. On the other hand, VOCs emission from kiln fed with Solid AFR 2 only is higher at raw mill off rather than raw mill on at $14.66 \mathrm{mg} / \mathrm{Nm}^{3}$ and 9.02 $\mathrm{mg} / \mathrm{Nm}^{3}$ respectively. 
In addition to VOCs concentration, the fraction of each VOCs element could be expected from Fig. 2. It can be seen that the largest fraction amongst VOCs is benzene followed by toluene at both conditions. However, the fraction of benzene and toluene are different depending on the types of AFR.

The fraction of benzene in Solid AFR 1 kiln is around $80 \%$ of total VOCs emission both for the raw mill on and raw mill off condition. In the Solid AFR 2 kiln, the portion of benzene is around $65 \%-70 \%$ of the total emission. For kiln using mixed fuel of Solid AFR 2 and biomass, benzene only takes part of around $60 \%$ of total VOCs. Then for the kiln fed with biomass only, the fraction of benzene is the smallest amongst other types of fuel at around $40 \%$ of total VOCs. It is expected that the utilization of biomass resulted in the lower fraction of benzene in the total VOCs emission.

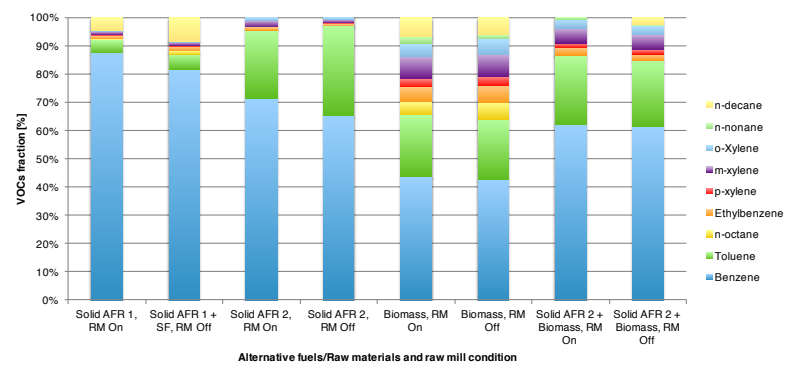

Fig. 2. Comparison of VOCs element fraction based on types of AFR

Another interesting finding from the VOCs element fraction is xylenes. The proportion of xylenes ( $p$-xylene, $\mathrm{m}$-xylene, and o-xylene) when biomass is involved tend to increase. Kiln substituted with solid AFR only shows the fraction of xylenes at around 2\% - 3\%. A significant increment is shown by the kiln fed with mixed fuel contained biomass that raises up to around $10 \%$ of xylenes from total VOCs. The highest fraction of xylenes is presented by the kiln utilized biomass only as AFR at around $15 \%-16 \%$ of its emission.

The total VOCs emission shows that there is a change between raw mill on and raw mill off condition. Nevertheless, the fraction of each VOCs element does not present any prominent difference in both conditions. The variation of VOCs element fraction more likely depends on the types of the fuel. Therefore, it can be stated that raw mill condition shows an impact towards VOCs concentration, yet do not affect the fraction of VOCs element.

Table 1 shows the mass balance of cement production that utilized Solid AFR or Biomass as alternative fuels and/or raw materials. It can be seen that in each condition the input materials including coals, AFR, and raw meal generate clinker as the product at around half of the amount of the input. Kiln 2 has larger production capacity so that the input of raw meal is almost one-half of kiln 1 .
The substitution rate of AFR could not be calculated through mass balance. From the amount of AFR put on the burner, the calculation of AFR substitution rate must involve the heating value. By using Eq. 1, the maximum substitution rate in term of energy is $15.76 \%, 21.23 \%$ for kiln 1 when raw mill on and off respectively, $16.43 \%$, and $19.38 \%$ for kiln 2 when raw mill on and off respectively.

Table 1. Balance of cement production

\begin{tabular}{|c|c|c|c|c|c|}
\hline \multirow[t]{2}{*}{ Parameter } & \multirow[t]{2}{*}{ Unit } & \multicolumn{2}{|c|}{ Kiln 1} & \multicolumn{2}{|c|}{ Kiln 2} \\
\hline & & $\begin{array}{c}\text { Raw } \\
\text { Mill } \\
\text { On }\end{array}$ & $\begin{array}{c}\text { Raw } \\
\text { Mill } \\
\text { Off }\end{array}$ & $\begin{array}{l}\text { Raw } \\
\text { Mill } \\
\text { On }\end{array}$ & $\begin{array}{c}\text { Raw } \\
\text { Mill } \\
\text { Off }\end{array}$ \\
\hline Fuels: & & & & & \\
\hline Coal (kiln) & ton $/ \mathrm{hr}$ & 18.20 & 15.33 & 13.16 & 12.86 \\
\hline $\begin{array}{l}\text { Coal } \\
\text { (calciner) }\end{array}$ & ton $/ \mathrm{hr}$ & 14.69 & 13.65 & - & - \\
\hline $\begin{array}{l}\text { Coal (inline } \\
\text { cyclone } \\
\text { preheater) }\end{array}$ & ton $/ \mathrm{hr}$ & - & - & 9.78 & 8.47 \\
\hline $\begin{array}{l}\text { Coal (side- } \\
\text { line cyclone } \\
\text { preheater) }\end{array}$ & ton $/ \mathrm{hr}$ & - & - & 28.85 & 24.08 \\
\hline Solid AFR & ton $/ \mathrm{hr}$ & 4.66 & 4.68 & - & - \\
\hline $\mathrm{SF}$ & ton $/ \mathrm{hr}$ & 0 & 1.28 & - & - \\
\hline Biomass & ton $/ \mathrm{hr}$ & - & - & 7.59 & 7.13 \\
\hline $\begin{array}{l}\text { Heating } \\
\text { value: }\end{array}$ & & & & & \\
\hline$\overline{\text { Coal }}$ & $\mathrm{kcal} / \mathrm{kg}$ & 4525 & 4525 & 4492 & 4492 \\
\hline Solid AFR & $\mathrm{kcal} / \mathrm{kg}$ & 4439 & 4439 & - & - \\
\hline $\mathrm{SF}$ & $\mathrm{kcal} / \mathrm{kg}$ & - & 4492 & - & - \\
\hline Biomass & $\mathrm{kcal} / \mathrm{kg}$ & - & - & 5362 & 5362 \\
\hline $\begin{array}{l}\text { Materials: } \\
\text { Raw meal }\end{array}$ & ton $/ \mathrm{hr}$ & 329.05 & 329.93 & 522.69 & 500.54 \\
\hline $\begin{array}{l}\text { Production: } \\
\text { Clinker }\end{array}$ & ton $/ \mathrm{hr}$ & 190.64 & 191.16 & 314.85 & 301.46 \\
\hline
\end{tabular}

Operating condition of cement kiln plan was recorded to show its influence towards BTEX emission. Record of operating condition was changing hourly. In Table 2, the record of the operating parameter is presented for maximum TSR condition.

During the record of operating condition, it can be inferred that kiln temperature was stable at $1366.7^{\circ} \mathrm{C}$ for kiln 1 and $1362.65^{\circ} \mathrm{C}$ for kiln 2 . Nonetheless, preheater temperature tends to fluctuate every hour from $822.92^{\circ} \mathrm{C}$ to $860.03^{\circ} \mathrm{C}$. The kiln speed changed by the time but only under $10 \%$. Residence time is calculated as the function of kiln speed so that it has a similar trend with the kiln speed.

Table 2. Kiln operating condition at maximum TSR

\begin{tabular}{|l|c|r|r|r|r|}
\hline \multirow{2}{*}{ Parameter } & \multirow{2}{*}{ Unit } & \multicolumn{2}{|c|}{ Kiln 1 } & \multicolumn{2}{c|}{ Kiln 2 } \\
\cline { 3 - 6 } & & $\begin{array}{c}\text { Raw } \\
\text { Mill } \\
\text { On }\end{array}$ & $\begin{array}{c}\text { Raw } \\
\text { Mill } \\
\text { Off }\end{array}$ & $\begin{array}{c}\text { Raw } \\
\text { Mill } \\
\text { On }\end{array}$ & $\begin{array}{c}\text { Raw } \\
\text { Mill } \\
\text { Off }\end{array}$ \\
\hline TSR & \%energy & 15.76 & 21.23 & 16.43 & 19.38 \\
\hline Operating & & 1366.7 & 1366.7 & 1362.65 & 1362.5 \\
\hline $\begin{array}{l}\text { Condition: } \\
\text { Kiln }\end{array}$ & ${ }^{\circ} \mathrm{C}$ & & & & \\
$\begin{array}{l}\text { Preheature } \\
\text { temperature }\end{array}$ & ${ }^{\circ} \mathrm{C}$ & 839.74 & 839.86 & 848.22 & 844.39 \\
$\begin{array}{l}\text { Kiln speed } \\
\begin{array}{l}\text { Residence } \\
\text { time }\end{array}\end{array}$ & rpm & 2.28 & 2.38 & 2.66 & 2.67 \\
\hline
\end{tabular}


The utilization of synthetic fuel at raw mill off condition is less than one-third of the whole amount of AFR (Table 1). The trend of VOCs emission between raw mill on and raw mill off condition is not affected by feeding SF into the kiln. In line with it, the trend of VOCs element fraction in the emission is not changed by the presence of SF. Thus, it is assumed that the utilization of SF as an additive at the raw mill off did not give significant impact to the VOCs emission.

Fatimah [9] have found that the utilization of AFR as substituted fuel has increased BTEX emissions up to 20 times compared to the kiln fed with coal only. The increment of VOCs emission from cement kiln stack is suspected due to the presence of AFR. To study the relationship between AFR and VOCs emission, physical and chemical characteristics of AFR as well as the operating condition of manufacturing process were analyzed. Physical and chemical characteristics of AFR along with kiln operating condition show an influence towards VOCs emission.

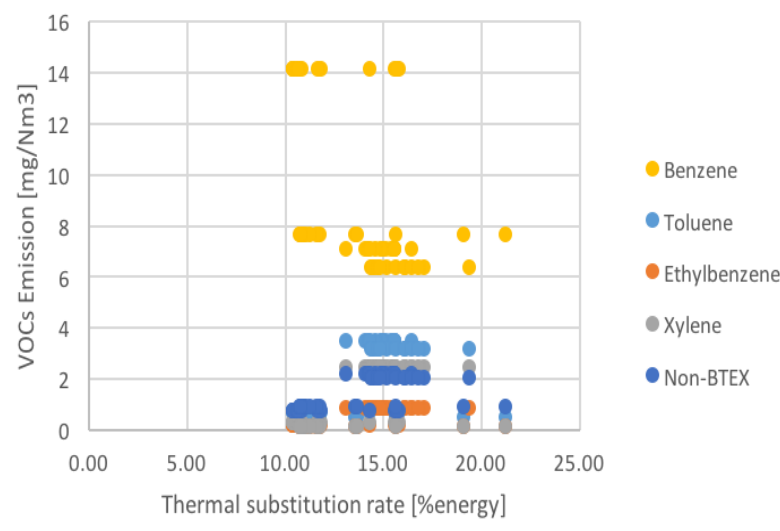

Fig. 3. Influence of thermal substitution rate towards VOCs emission

TSR represents the quantity of AFR involved in the combustion process inside the kiln. The higher the TSR imply the higher amount of carbon originated from AFR that suspected the source of VOCs emission. Fig. 3 shows how TSR affect VOCs emission.

It can be seen that increase of AFR substitution rate result in the increase of toluene, ethyl-benzene, xylene, octane, nonane, and decane emission, except benzene. Benzene is the only organic compound tends to decrease in emission by the increase in substitution rate of alternative fuels. The explanation of this condition may relate to the relationship between VOCs emissions and organic carbon content in the alternative fuels. Emission of benzene is expected not only comes from thermal decomposition of organic carbon content in the alternative fuels but also from other organic materials inside the preheater.

Fig. 4 shows the relationship between VOCs emission and preheater temperature. Each VOCs element i.e. toluene, ethylbenzene, xylene, octane, nonane, and decane tend to decrease with the increase of preheater temperature, except benzene. As previous findings, benzene shows different result compared to other compounds. Emission of benzene tends to increase when preheater temperature is increased.

Preheater temperatures are varied from 823 to $860^{\circ} \mathrm{C}$ inside the preheater during the sampling period. The release of organic compounds in the kiln system occurred in temperature between $400-600^{\circ} \mathrm{C}$ [15]. At the temperatures over $600^{\circ} \mathrm{C}$, the organic compounds inside burner tend to be destructed. Thus, the higher the temperature the lower the VOCs emission.

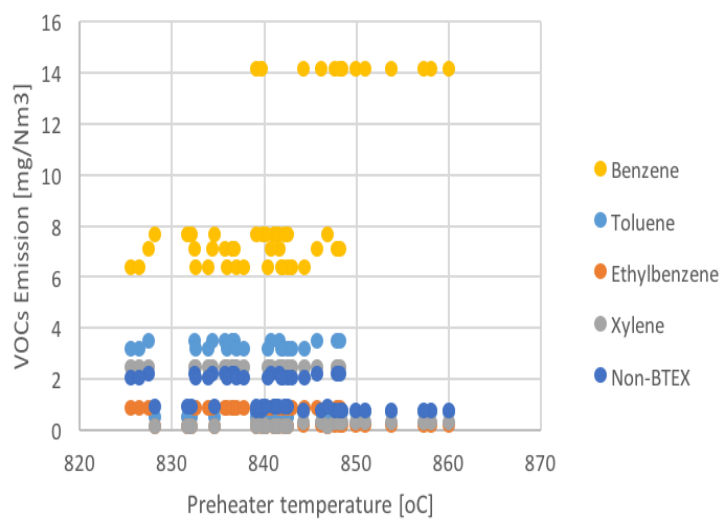

Fig. 4. Influence of preheater temperature towards VOCs emission

The special case about benzene is that at the temperature range of $823^{\circ} \mathrm{C}$ and $860^{\circ} \mathrm{C}$ inside preheater, its concentration tends to increase. When VOCs are exposed to high temperatures, it will crack into lighter hydrocarbon species (HCs), but some of the HCs will not be oxidized and the remaining $\mathrm{HC}$ could be considered as a whole and called total hydrocarbons (THC) (Salvador et al., 2006). Referred to Kara [18], oxidation of VOCs may occur if flame temperatures in the burner are kept around $1000^{\circ} \mathrm{C}-2000^{\circ} \mathrm{C}$. Thus, there is a possibility that the destruction temperature of benzene is not achieved at the temperature range of preheater.

The unachieved destruction temperature for benzene is expected due to formation rate of is higher than its oxidation rate. Benzene is the most stable compound compared to other VOCs detected in the flue gas due to its ring structure. The more stable the compound, the higher the required energy to oxidize it. Therefore, benzene is the most difficult compound to be oxidized compared to other VOCs element. It is described in the standard $\left(25^{\circ} \mathrm{C}\right)$ combustion enthalpy of benzene in the gas phase $\left(-\Delta_{\mathrm{c}} \mathrm{H}^{\mathrm{o}}\right.$ gas $)$ that has smallest value $789,08 \pm 0,10$ $\mathrm{kcal} / \mathrm{mol}$ (toluene $=943,58 \pm 0,12 \mathrm{kcal} / \mathrm{mol}$; ethylbenzene $=1101,13 \pm 0,17 \mathrm{kcal} / \mathrm{mol} ; \mathrm{p}$-xylene $=1098,29 \pm 0,22$ $\mathrm{kcal} / \mathrm{mol} ;$ m-xylene $=1098,12 \pm 0,15 \mathrm{kcal} / \mathrm{mol} ;$ o-xylene $=1098,54 \pm 0,24 \mathrm{kcal} / \mathrm{mol} ; \mathrm{n}$-octane $=1317,45 \pm 0,16$ $\mathrm{kcal} / \mathrm{mol}$; n-nonane $=1474,90 \pm 0,18 \mathrm{kcal} / \mathrm{mol}$; and $\mathrm{n}$ decane $=1632,34 \pm 0,21 \mathrm{kcal} / \mathrm{mol}$ ) [17]. Based on the 
comparison of standard combustion enthalpy value, benzene has the smallest amount of released energy due to high energy required to oxidize it. It could explain why the rate of benzene oxidation is the least compared to other compounds so that emission of benzene tends to increase when the temperature is increased.

The influence of kiln speed towards VOCs emission is shown in Fig. 5. Emissions of toluene, ethylbenzene, xylene, and other VOCs non-BTEX tend to increase when kiln speed is increased. However, benzene is the only compound that tends to decrease when kiln speed is increased.

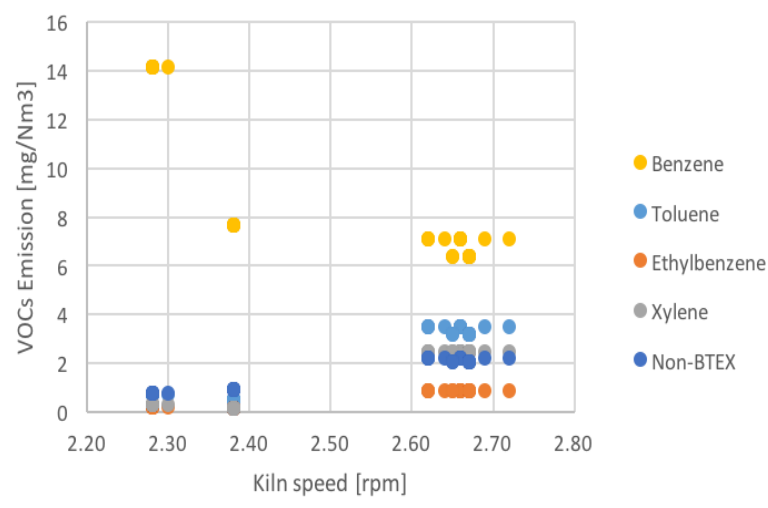

Fig. 5. Influence of kiln speed towards VOCs emission

Kiln speed is related to turbulence, which is an indicator showing the effectiveness of contact between material and oxygen inside rotary kiln [18]. It indicates that the higher the kiln speed, the higher the airflow rate inside burner so that turbulence becomes higher. As the turbulence increase, the effectiveness of oxygen contact with materials inside kiln is also increased. However, increase in airflow rate due to an increase of kiln speed, induce lower global fuel richness inside the flame of the burner, whose temperature will decrease [19]. As implied in the relationship between preheater temperature and VOCs emission, the decrement of temperature could lead to increase of VOCs emission.

For the benzene case, it is expected that increase of kiln speed result in the increase of benzene oxidation rate. As the kiln speed higher, the turbulence, as well as airflow rate inside the burner, become higher. The airflow rate supports materials oxidation as well as the gas inside the burner. Hence, an increase of kiln speed affects to the decreased of benzene concentration.

Fig. 6 represents the relationship between material residence time and VOCs emission. It is showed that increase of material residence time results in the decrease of VOCs emission except for benzene. Similar to the previous findings, benzene always shows different results with other VOCs.

The material residence time is obtained from a calculation involving the data of kiln speed. From the Eq. 2 it can be seen that material residence is inversely proportional to the kiln speed. The longer the time of material in the kiln, the lower the kiln speed. It is expected that increase of material residence time will increase the degree of effectiveness of the oxidation process both for materials and its gas. Therefore, the longer the material residence time results in the lower VOCs emission.

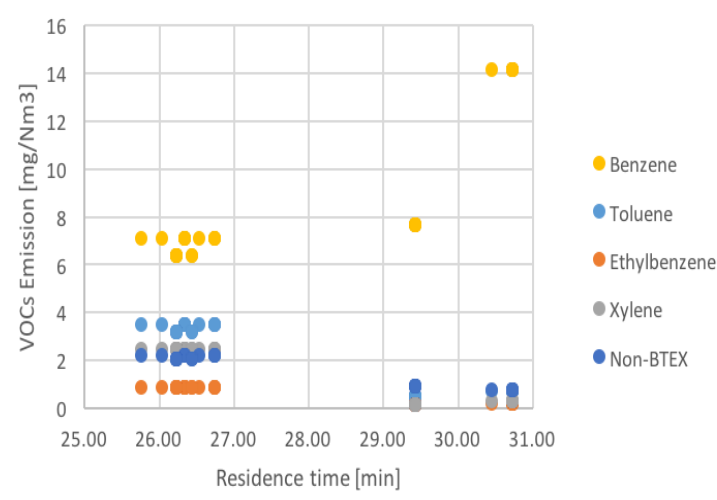

Fig. 6. Influence of residence time towards VOCs emission

The relationship between material residence time and VOCs emissions i.e. toluene, ethyl-benzene, xylene, and the non-BTEX, is not applicable for benzene. The concentration of benzene tends to increase by the increase of material residence time. The material residence time is related to the degree of effective oxidation. Nonetheless, the oxidation of materials and the exhaust gas not only depends on the residence time but also the temperature. Benzene is the compound that requires the highest energy for oxidation compared to other VOCs. Thus, the increase of residence time does not result in the decrease of benzene concentration due to high oxidation energy demand of benzene.

\section{Conclusion}

VOCs emissions from cement kiln stack consisted of benzene, toluene, ethyl-benzene, p-xylene, m-xylene, oxylene, n-octane, n-nonane, and n-decane are vary based on alternative fuels. VOCs emissions from kiln feeding biomass, biomass mixed solid AFR, solid AFR (2014) and solid AFR (2015) are 15.68 $\pm 2.23 \mathrm{mg} / \mathrm{Nm}^{3}$; $13.1 \pm 4.42 \mathrm{mg} / \mathrm{Nm}^{3} ; \quad 12.40 \pm 3.25 \mathrm{mg} / \mathrm{Nm}^{3} ;$ and $11.96 \pm 4.32 \mathrm{mg} / \mathrm{Nm}^{3}$ consecutively. Overall, benzene and toluene are compounds that exist in the highest concentration from all alternative fuels. Benzene concentration from kiln feeding solid AFR, biomass, or biomass mixed with solid AFR are in range 6.46-14.14 $\mathrm{mg} / \mathrm{Nm}^{3}(43.29-85.31 \%)$ and toluene are in range 0.71 $-3.51 \mathrm{mg} / \mathrm{Nm}^{3}(4.73-29.46 \%)$.

The cement kiln stack feeding alternative fuels tends to generate higher VOCs emission at the condition of the raw mill on rather than the raw mill off. The condition of raw mill affects the total VOCs concentration but does not change the fraction of each VOCs element. The fraction of VOCs element more depends on the types of alternative fuels. The utilization of biomass shows a decrement of benzene proportion and an increment of xylenes proportion of all VOCs. 
A relationship between each VOCs emission and operating condition, for instance, thermal substitution rate, preheater temperature, kiln speed, and material residence time exist. Nonetheless, benzene always shows different trend amongst other VOCs. The high oxidation energy demand of benzene compared to the other compounds is suspected to be the main reason of benzene shows a distinct behavior.

\section{Nomenclature}

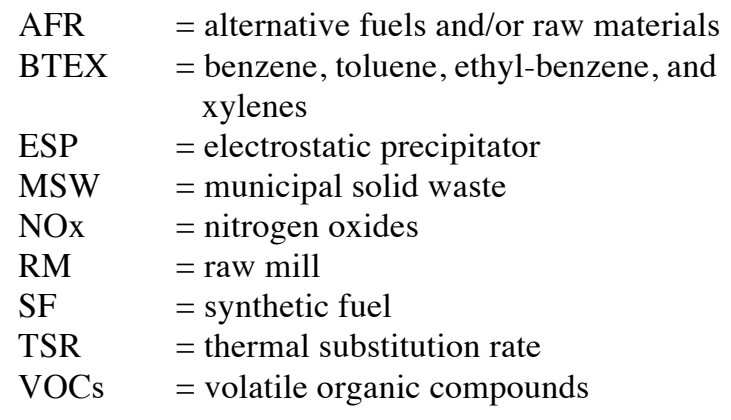

\section{References}

1. BPS, Statistik Industri Besar dan Sedang (2012)

2. W. Queiroz Lamas et al, Ren. and Sust. Energy Reviews, 19, 200-207 (2013)

3. A. Ottoboni, I. De Souza, G.J. Menon, R.J. Da Silva, Energy Convers. Mgmt, 39, 1899-1909 (1998)

4. G. Mardiana, R. Mahardika, Seminar Rekayasa Kimia dan Proses (2010)

5. F.D. Qonitan, Scientific Reports Dept. of Env. Eng. (2013)

6. L. Zi-feng, H. Ji-ming, D. Jing-chun, L. Jun-hua, 30, 969-975 (2009)

7. L. Kun, W. Weigang, G. Maofa, L. Jiangjun, W. Dong, Scientific Reports (2014)

8. P. Villeneuve, M. Jerrett, J. Su, R. Burnett, H. Chen. J. Brook, Env. Pol., 183, 30-39 (2013)

9. R. Fatimah, Scientific Reports Dept. of Env. Eng. (2008)

10. A. Chatterjee, Cem. and Concr. Rsrch, 41, 624-641 (2011)

11. VDZ, Scientific Reports (2008)

12. EPA, Scientific Reports (1994)

13. WBCSD, World Business Council for Sustainable Development (2012)

14. W. Greer, Portland Cement Association Research (2003)

15. EU, IPPC Bureau (2013)

16. Y. Kara, The`se de Doctorat (Ph.D.) (2003)

17. E. Prosen, W. Johnson, F. Rossini, J. Res. NBS, 36, 455-461 (1946)

18. D.G. Wilson, Handbook of Solid Waste Management, (1977)

19. S. Salvador, Y. Kara, J. Commandre, Applied Thermal Engineering, 26, 1640-1651 (2006) 